V. N. Efremov ${ }^{1}$, E. Z. Golosman ${ }^{1}$, A. V. Kashinskaya ${ }^{1}$, T. I. Mugenov' ${ }^{2}$, V. E. Zolotareva ${ }^{2}$, B. I. Polivanov' ${ }^{1}$ A. P. Polushin ${ }^{3}$ ${ }^{1} \mathrm{OOO}$ «NIAP-Katalizator» 10 Svyazi st., Novomoskovsk, Tul'skaya obl., 301660, Russia

${ }^{2}$ Novomoskovsk Institute (branch) of the Dmitry Mendeleev University of Chemical Technology of Russia 8 Druzhby st., Novomoskovsk, Tul'skaya obl., 301665, Russia ${ }^{3} J S C$ «Novomoskovsk joint stock company AZOT» Svyazi st., Novomoskovsk, Tul'skaya obl., 301660, Russia e-mail:evgolosman.niap@yandex.ru

\title{
Resistance of industrial nickel-containing methanation catalysts to the poisoning by organic carbon dioxide absorbents
}

We report the results of studies on the influences of the organic carbon dioxide absorbent - aqueous solution of activated methyldiethanolamine (MDEA) - on the physico-chemical and mechanical characteristics of nickel-alumina catalyst NIAP-07-01 (NKM-1) and cement-containing catalysts NIAP-0707 (NKM-7), Meth-134 and Meth-135 for the hydrogenation of carbon oxide (methanation). It is established that for the nickel-alumina and nickel-cementcontaining catalysts subjected to activated methyldiethanolamine (MDEA) it's possible to restore their strength and catalytic properties.

In order to increase the time of operation of the methanator it is recommended to apply a new Nickel cement-containing catalyst NIAP-07-07 (NKM-7), which can be produced as tablets, rings or extrudates.

Keywords: nickel-containing catalyst; calcium aluminate; methantion; solution of methyldiethanolamine; hydrogenation; carbon oxides; catalytic activity; mechanical strength.

Received: 16.06.2017; accepted: 06.09.2017; published: 20.10.2017. 
В. Н. Ефремов ${ }^{1}$, Е. З. Голосман ${ }^{1}$, А. В. Кашинская ${ }^{1}$,

Т. И. Мугенов ${ }^{2}$, В. Е. Золотарева ${ }^{2}$,

Б. И. Поливанов ${ }^{1}$, А. П. Полушин ${ }^{3}$

${ }^{1} \mathrm{OOО}$ «НИАП-Катализатор»

ул. Связи 10, г. Новомосковск, Тульская обл., 301660, Россия

${ }^{2}$ Новомосковский институт (филиал) Российского химико-технологического университета имени Д. И. Менделеева

ул. Дружбы 8, г. Новомосковск, Тульская обл., 301665, Россия ${ }^{3} \mathrm{AO}$ «Новомосковская акционерная компания «АЗОТ» ул. Связи, г. Новомосковск, Тульская обл., 301660, Россия e-mail:evgolosman.niap@yandex.ru

\section{Устойчивость никелевых промышленных катализаторов метанирования к воздействию органических абсорбентов удаления диоксида углерода из синтез-газа}

Приведены результаты исследований воздействия органического абсорбента в виде водного раствора активированного метилдиэтаноламина (МДЭА), являющегося абсорбентом диоксида углерода при его удалении из азото-водородной смеси, на физико-химические и физико-механические характеристики никельалюминиевого марки НИАП-07-01 (НКМ-1) и цементсодержащих марки НИАП-07-07 (НКМ-7), Meth-134 и Meth-135 катализаторов гидрирования оксидов углерода (метанирования). Установлено, что никельалюминиевые и никельцементсодержащие катализаторы, подвергнутые воздействию активированного метилдиэтаноламина (МДЭА), восстанавливают свои прочностные и каталитические свойства.

Для увеличения времени эксплуатации метанатора рекомендуется применять новый никелевый цементсодержащий катализатор марки НИАП-07-07 (НКМ-7), который может изготавливаться в виде таблеток, колец или экструдатов.

Ключевые слова: никелевый катализатор; алюминат кальция; метанирование; раствор метилдиэтаноламина; гидрирование; оксиды углерода; каталитическая активность; механическая прочность.

Поступило: 16.06.2017; принято: 06.09.2017; опубликовано: 20.10.2017.

(C) Efremov V.N., Golosman E.Z., Kashinskaya A.V., Mugenov T.I., Zolotareva V.E., Polivanov B. I., Polushin A. P., 2017

\section{Introduction}

In the USSR, Russia and CIS Katalizator»: nickel-aluminum catalyst the most commonly used catalysts of the NIAP-07-01 (NKM-1), nickel cement-conhydrogenation of carbon oxide (metha- taining ones - NIAP-07-02, NIAP-07-03 nation) are those developed by «NIAP- (NKM-4A), and nickel-chromia-alumina- 
containing TO-2M [1-5]. These catalysts are manufactured according to TU2178003-00209510-2006 by the «NIAP-Katalizator» factory, and until recently they were also produced by Dorogobuzhskiy catalyst factory and Severo-Donetsk catalyst production plant. As for now, these catalysts are produced solely by «NIAPKatalizator». Their planned service life is usually about 15-16 years, while the actual service life amounted to $22-24$ years [6] on the three JSC «AZOT» factories (Nevinnomyssk, Voronezh, Grodno).

Note that there are some imported catalysts of methanation supplied by «Haldor Topsoe», "Johnson Matthey» and «CLARIANT» (Sud-Chemie). The «NIAP-Katalizator»-made catalysts are being produced as tablets or rings in accordance with the technical requirements of TU2178-003-00209510-2006 (catalysts of methanation). For the Russian market the imported catalysts are also available as tablets, and in addition - as extrudates and beads.

The methanation catalysts must have high activity in the hydrogenation process, leaving no more than 5-10 ppm of residual $\mathrm{CO}$ after the methanation of $0.3-$ $0.7 \% \mathrm{CO}$ and $0.02-0.1 \% \mathrm{CO}_{2}$ mixture. They have to possess increased thermal stability without reducing their catalytic activity (overheating up to $550-650{ }^{\circ} \mathrm{C}$ can occur in cases of increasing the $\mathrm{CO}$ content in the source gas to more than $1 \%)$, high mechanical strength and low gas flow resistance.

The quality of the methanation catalysts is largely determined by their support. In the domestic and imported industrial methanation catalysts various supports are used, for example, $\gamma-\mathrm{Al}_{2} \mathrm{O}_{3}$, calcium aluminates, compounds of $\mathrm{CaO}$ $\mathrm{MgO}, \quad \gamma-\mathrm{Al}_{2} \mathrm{O}_{3}-\mathrm{Cr}_{2} \mathrm{O}_{3}, \quad \gamma-\mathrm{Al}_{2} \mathrm{O}_{3}$, calcium aluminate, boehmite $(\mathrm{AlOOH})-\gamma-\mathrm{Al}_{2} \mathrm{O}_{3}$ [7-9].

The content of active component $(\mathrm{NiO})$ in the industrial methanation catalysts varies in the range of 25.0 to $45.0 \mathrm{wt}$. \%. Catalysts NIAP-07-02, NIAP-07-03, and KATALKO-11-4R, Meth-134 and Meth-135, in which calcium aluminate plays the role of the adhesive, have a minimum level of internal microstresses, which contributes to the high mechanical strength after the catalyst's activation and during its operation. Note that the service life of a catalyst is primarily determined by its catalytic activity and mechanical strength.

The experience of running industrial catalytic plants used in various chemical, petrochemical, metallurgical and other industries, as well as available literature data and our long-term monitoring of the industrial catalytic set-ups developed by «NIAP-Katalizator» allowed us to assess the reasons for their deactivation. The deactivation of the methanation catalysts may occur due to:

1. Irreversible poisoning associated with the interaction of the active component with the common catalyst poisons (sulfur compounds, chlorides etc.) present in the reaction medium.

2. Consequences of the thermal treatment, such as recrystallization, caking, the chemical interactions of active component with the support (e.g. resulting in the formation of the nickel-aluminum spinel $\mathrm{NiAl}_{2} \mathrm{O}_{4}$ ).

3. Loss of the active component due to the formation of volatile compounds such as tetracarbonylnickel.

4. Carbon deposition on the catalyst's surface.

5. Catalyst's surface contamination by various impurities. 
The structural changes of the industrial porous catalysts are accelerated if the phase transformations occur upon the exposure to the reaction medium.

Under the working conditions of the large-capacity catalytic unit, the absorbents used to remove $\mathrm{CO}_{2}$ from syngas or their decomposition products could possibly poison the catalyst. In industrial conditions this process occurs in the absorbers with absorbents such as aqueous alkaline solutions («Banfield» and «Kar-

\section{Experimental}

Industrial catalysts NIAP-07-01 (NKM-1) and the NIAP-07-07 (NKM-7), the latter being recommended for industrial use, were chosen as the objects of this research. NIAP-07-07 (NKM-7) was obtained in two states: 1 - non-calcined; 2 - calcined at $400{ }^{\circ} \mathrm{C}$. It can be manufactured as cylindrical tablets, extrudates or in toroidal form from the same non-calcined catalyst mixture. The catalyst in the form of rings has a low gas flow resistance, which leads to significant savings of natural gas in the operation of the ammoniasynthesis units. In addition, imported catalysts Meth-135 (C13-03-3) and Meth-134 (C13-04-4) were investigated.

$\mathrm{X}$-ray diffraction (XRD) studies of the phase composition and size of crystallites were performed using DRON-3 diffractometer ( $\mathrm{CuKa}$-radiation with graphite monochromator on reflected beam). For the phase analysis ICDD PDF-2 (1999) database was used. Thermogravimetric analysis (TGA) was performed using the optical derivatograph OD-103 with the heating rate of $5{ }^{\circ} \mathrm{C} / \mathrm{min}$. Total specific surface area was determined by the low-temperature nitrogen sorption in the vacuum adsorption setup. Total porosity was calculated from the data of real and sol»), and organic absorbents such as aqueous solutions of activated monoethanolamine (MEA) or methyldiethanolamine (MDEA) $[10,11]$. During the operation, carbon dioxide absorbents could get into the methanation reactor. As a result, a gradual decrease of catalytic activity may occur $[12,13]$.

To determine the causes of this phenomenon, we conducted studies in which the methanation catalysts were influenced by the organic absorbent MDEA.

theoretical density. Mechanical strength was determined on the «MП-2C» setup by crashing the granules with the uniaxial compressive force. The chemical composition and catalytic activity during the methanation were determined in the original setup at a pressure of $3 \mathrm{MPa}$ by means of the techniques described in the TU2178-003-00209510. According to this internal standard, we adopt the following definition of a catalytic activity: it's a minimum temperature in ${ }^{\circ} \mathrm{C}$, at which the volume fraction of $\mathrm{CO}$ at the output of the catalytic reactor is less than $1 \cdot 10^{-3} \%$ at a pressure of $3 \mathrm{MPa}$. The other important experiment conditions are as follows: feed gas with $0.6-0.7$ vol. \% of CO, space velocity of the feed gas should be equal to $4000 \mathrm{~h}^{-1}$, and the catalyst in the catalytic reactor should be pre-heated for $10 \mathrm{~h}$ at $550{ }^{\circ} \mathrm{C}$.

The treatment of all investigated catalysts by $50 \%$ aqueous solution of MDEA absorbent in the flow of nitrogen-hydrogen mixture $\left(75\right.$ vol. $\% \mathrm{H}_{2}, 25$ vol. $\% \mathrm{~N}_{2}$ ) was carried out in the original setup, schematic of which is shown in Fig. 1.

Before the experiments catalysts were activated in a stream of nitrogen-hydrogen mixture (NHM) at $400{ }^{\circ} \mathrm{C}$ for $5 \mathrm{~h}$. At 
the end of the activation process the samples were exposed to aqueous solution of
MDEA in the stream of NHM in the layer catalyst at a temperature of $320^{\circ} \mathrm{C}$.

\section{Results and discussion}

In order to determine the influence of the absorbents on the catalysts' properties their initial characteristics were determined (Table 1). Data given in Table 1 show that the catalysts under investigation possess $27-40 \mathrm{wt}$. \% of the Ni-containing active component with weight percentage calculated implying that $\mathrm{NiO}$ is the active component's only form. The average $\mathrm{NiO}$ particle size in NIAP-07-01 (NKM1) and NIAP-07-07 (NKM-7) is around 60-80 A. Total porosity is almost equal for all catalysts, its value being around 48$57 \%$. The only exception is NIAP-07-07, for which it's $29 \%$. Note that the porous structure of this catalyst forms during the combined calcination and activation process, which could explain this unique po-

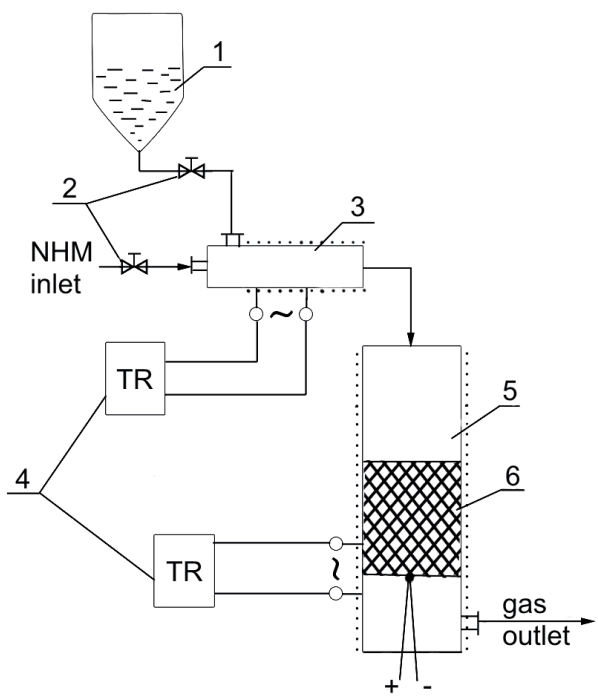

Fig. 1. Schematic diagram of a setup for catalyst treatment by the aqueous solution of the absorbent in the flow of nitrogenhydrogen mixture (NHM):

1 - MDEA solution; 2 - flow regulators;

3 - evaporator; 4 - temperature regulators; 5 - reactor; 6 - catalyst rosity value. All catalysts have quite large total surface area, with the largest value of $180 \mathrm{~m}^{2} / \mathrm{g}$ corresponding to NIAP-07-01 (NKM-1).

It should be noted that the mechanical strength of studied samples, which is one of the parameters determining the service life of a catalyst, varies significantly. The «strongest» catalyst is NIAP-07-07 (NKM-7) - $60 \mathrm{MPa}$, followed by NIAP-07-01 (NKM-1) - 29 MPa. Strength of the Meth-134 and Meth-135 is almost equal.

Phase composition and $\mathrm{NiO}$ particle size analysis (Table 1) shows that the aluminate cement is one of the components of the support for Meth-134, Meth-135 and NIAP-07-07 (NKM-7) catalysts. As the second component of the support for NIAP-07 (NKM) is $\gamma-\mathrm{Al}_{2} \mathrm{O}_{3}$, for the Meth134 and Meth-135 catalysts it consists of the mixture of boehmite $(\mathrm{AlOOH})$ and $\gamma-\mathrm{Al}_{2} \mathrm{O}_{3}$. Boehmite as a support constituent could impede the catalyst's activity as it inhibits the interaction between support and the active component.

The active component of raw NIAP07-07 catalyst is a complex compound nickel hydroxocarboaluminate (NHCA). It's the main difference between the raw NIAP-07-07 and NIAP-07-01, fired NIAP-07-07 and Meth catalysts. Activation of NIAP-07-07, coupled with the NHCA decomposition, occurs at the lower temperatures (thus - at milder conditions) as compared to the other industrial catalysts with $\mathrm{NiO}$ as an active component.

Since the industrial catalytic reactors are operated at about $280-320{ }^{\circ} \mathrm{C}$, we had to determine the thermal stability of 
Table 1

Physico-mechanical and physico-chemical characteristics of the original catalysts for the methanation: $\mathrm{P}$ - porosity, $\mathrm{S}$ - specific surface area

\begin{tabular}{|c|c|c|c|c|c|c|c|c|c|c|}
\hline \multirow{2}{*}{$\begin{array}{l}\text { Brand of the } \\
\text { catalyst }\end{array}$} & \multirow{2}{*}{$\begin{array}{l}\text { The } \\
\text { geometric } \\
\text { dimen- } \\
\text { sions, } \mathrm{mm}\end{array}$} & \multirow{2}{*}{$\begin{array}{l}\text { Bulk } \\
\text { density, } \\
\mathrm{kg} / \mathrm{dm}^{3}\end{array}$} & \multirow{2}{*}{$\begin{array}{c}\text { Mechanical } \\
\text { strength, } \\
\mathrm{MPa} \\
\mathrm{P}_{\text {avg }} / \mathrm{P}_{\min } \\
\end{array}$} & \multirow{2}{*}{$\begin{array}{c}\mathrm{S} \\
\mathrm{m}^{2} / \mathrm{g}\end{array}$} & \multirow{2}{*}{$\begin{array}{l}\mathrm{P}, \\
\%\end{array}$} & \multirow{2}{*}{$\begin{array}{c}\text { XRD phase analysis } \\
\text { results }\end{array}$} & \multirow{2}{*}{$\begin{array}{c}\mathrm{L}_{\mathrm{NiO}} \\
\AA\end{array}$} & \multicolumn{3}{|c|}{$\begin{array}{l}\text { Chem. composi- } \\
\text { tion, \% mass. }\end{array}$} \\
\hline & & & & & & & & $\mathrm{NiO}$ & $\mathrm{Al}_{2} \mathrm{O}_{3}$ & $\mathrm{CaO}$ \\
\hline $\begin{array}{l}\text { NIAP-07-01 } \\
(\mathrm{NKM}-1)\end{array}$ & $\begin{array}{c}\text { Tablet } \\
6 \times 5\end{array}$ & 1.08 & $29 / 20$ & 180 & 57 & $\begin{array}{c}\gamma-\mathrm{Al}_{2} \mathrm{O}_{3}, \mathrm{NiO}, \\
\text { graphite }\end{array}$ & 60 & 33.6 & 61.3 & - \\
\hline $\begin{array}{l}\text { NIAP-07-07 } \\
(\text { NKM-7) }\end{array}$ & $\begin{array}{c}\text { Tablet } \\
6 \times 5\end{array}$ & 1.2 & $60 / 52$ & 102 & 29 & \begin{tabular}{|c|}
$\mathrm{NHCA}$, graphite, \\
$\mathrm{CaCO}_{3}$ (aragonite) - \\
not much, $\mathrm{Al}(\mathrm{OH})_{3}$ \\
$\mathrm{CaO} \cdot 2 \mathrm{Al}_{2} \mathrm{O}_{3}-$ not \\
much \\
\end{tabular} & - & 30.3 & 25.2 & 7.9 \\
\hline $\begin{array}{c}\text { NIAP-07-07 } \\
(\mathrm{NKM}-7) \text { fired } \\
\text { at } 450{ }^{\circ} \mathrm{C} \\
\end{array}$ & $\begin{array}{c}\text { Tablet } \\
6 \times 5\end{array}$ & 1.1 & $49 / 32$ & 160 & 53 & \begin{tabular}{c|}
$\mathrm{NiO}, \gamma-\mathrm{Al}_{2} \mathrm{O}_{3}$, \\
$\mathrm{CaO} \cdot \mathrm{Al}_{2} \mathrm{O}_{3}$, \\
$\mathrm{CaO} \cdot 2 \mathrm{Al}_{2} \mathrm{O}_{3}$, graphite \\
\end{tabular} & 75 & 30.3 & & \\
\hline $\begin{array}{l}\text { Meth-134 } \\
\text { (C13-04-4) }\end{array}$ & $\begin{array}{l}\text { Sphere } \\
d=4.3\end{array}$ & 0.95 & $8 / 4$ & 150 & 48 & $\begin{array}{c}\mathrm{NiO}, \mathrm{AlOOH}, \\
\gamma-\mathrm{Al}_{2} \mathrm{O}_{3}, \mathrm{CaCO}_{3} \\
\text { (boehmite) }\end{array}$ & 80 & 27.2 & 57.3 & 10.0 \\
\hline $\begin{array}{l}\text { Meth-135 } \\
\text { (C13-03-3) }\end{array}$ & $\begin{array}{l}\text { Sphere } \\
d=5.3\end{array}$ & 0.99 & $6 / 1$ & 120 & 54 & $\begin{array}{c}\mathrm{NiO}, \mathrm{AlOOH}, \\
\gamma-\mathrm{Al}_{2} \mathrm{O}_{3}, \mathrm{CaCO}_{3} \\
\text { (boehmite) }\end{array}$ & 80 & 40.4 & 42.9 & 11.2 \\
\hline
\end{tabular}

MDEA in this temperature range. Therefore, the sample of $\alpha-\mathrm{Al}_{2} \mathrm{O}_{3}$ impregnated with the aqueous solution of MDEA was investigated by means of thermogravimetric analysis. On the differential thermogravimetric (DTG) curve, shown in Fig. 2, two distinct minima at the temperatures of $100{ }^{\circ} \mathrm{C}$ and $210{ }^{\circ} \mathrm{C}$ can be observed. They correspond to the maximum speed of removal of water from the sample and the decomposition of MDEA, accordingly. The process of decomposition of MDEA in air, accompanied by the mass loss, starts at about $150^{\circ} \mathrm{C}$ and ends at $300^{\circ} \mathrm{C}$.

In order to determine the optimal activation temperature of a catalyst a temperature-programmed reduction experiments were employed. It was determined that the activation is a multistage process. It should be noted that NIAP-07-07 (NKM-7) catalyst is activated at about $100{ }^{\circ} \mathrm{C}$ lower temperatures than the other studied catalysts. XRD analysis shows that

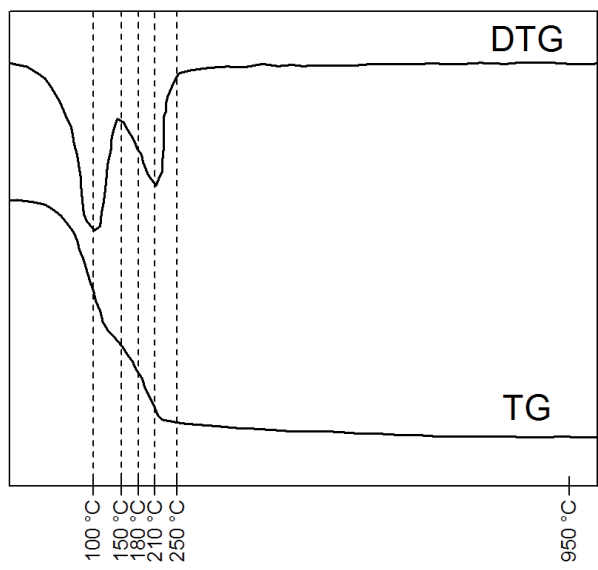

Fig. 2. TGA curve of the sample of $\alpha$-alumina, impregnated with water solution of MDEA

at $400{ }^{\circ} \mathrm{C}$ the activation process is virtually complete. Comparison of the Ni-containing particle sizes shows that for all catalysts after the activation it still is in the range of $60-80 \AA$.

Physico-chemical and mechanical properties of the activated catalysts treated with MDEA solution are listed in the Table 2 along with their catalytic activities 
towards the methanation. Characteristic feature of the interaction between MDEA solution and the catalyst is the initial rise of the temperature at the beginning of the reaction. It could be related to the passivation of a catalyst by the water vapor, which is formed during the evaporation of MDEA aqueous solution. XRD pattern analysis confirmed that in this case passivation of the active component occurs, effectively removing part of it from the catalysis process. The activated catalysts treated with MDEA solution in NHM gas flow contain the mixture of $\mathrm{Ni}$ and $\mathrm{NiO}$ phases, which is an evidence in favor of our assumption. Particular ratio of the mentioned phases should depend on how reduced the catalyst was and how much of metallic Ni it contains. Hence the samples before the catalytic activity measurements have been pre-treated at $400^{\circ} \mathrm{C}$ for $8 \mathrm{~h}$.

According to XRD, MDEA does not chemically alter the supports of the investigated catalysts for methanation. However, due to the fact that MDEA (tertiary amine) is an adsorbtion-active agent, it could negatively affect the properties of catalysts, namely, mechanical strength, specific surface area, porosity and catalytic activity. The results of our studies given in Table 2 show that after exposure to the aqueous solution of MDEA in the nitrogen-hydrogen gas mixture flow the mechanical strength and specific surface area were only insignificantly reduced. The one exception is NIAP-07-07 (NKM-7), for which the microstructure forms during the activation process. Total porosity is almost equal for all samples. Phase changes occurred during the reaction with MDEA are related to the catalysts' passivation. Comparison of the catalytic activity data show that the catalysts treated with aqueous MDEA solution in NHM flow at $320{ }^{\circ} \mathrm{C}$ retain their catalytic properties almost completely. The particular catalytic activities are comparable to those defined in our TU2178-003-00209510-2006 internal standard (typically being in the range from $170{ }^{\circ} \mathrm{C}$ to $200{ }^{\circ} \mathrm{C}$ ) for methanation catalysts containing $31-40 \%$ of active component $(\mathrm{NiO})$.

Table 2

Physico-chemical and mechanical characteristics of the catalysts for methanation after exposure to MDEA

\begin{tabular}{|c|c|c|c|c|c|c|}
\hline \multirow[b]{2}{*}{$\begin{array}{l}\text { Brand of } \\
\text { catalyst }\end{array}$} & \multirow[b]{2}{*}{$\begin{array}{c}\text { Mechanical } \\
\text { strength, } \mathrm{MPa} \\
\mathrm{R}_{\mathrm{SR}} / \mathrm{P}_{\min }\end{array}$} & \multirow[b]{2}{*}{$\mathrm{S}, \mathrm{m}^{2} / \mathrm{g}$} & \multirow[b]{2}{*}{$\mathrm{P}, \%$} & \multirow[b]{2}{*}{$\begin{array}{c}\text { Phase } \\
\text { composition }\end{array}$} & \multicolumn{2}{|c|}{ Catalytic activity, ${ }^{\circ} \mathrm{C}$} \\
\hline & & & & & Initial samples & $\begin{array}{c}\text { After } \\
\text { exposure to } \\
\text { MDEA }\end{array}$ \\
\hline $\begin{array}{l}\text { NIAP-07-01 } \\
\text { NKM-1 }\end{array}$ & $27 / 19$ & 155 & 54 & $\begin{array}{l}\mathrm{NiO}, \mathrm{Ni}, \\
\text { graphite, } \\
\gamma-\mathrm{Al}_{2} \mathrm{O}_{3}\end{array}$ & 160 & 165 \\
\hline $\begin{array}{l}\text { NIAP-07-07 } \\
\text { NKM-7 }\end{array}$ & $41 / 35$ & 168 & 41 & $\begin{array}{c}\mathrm{NiO}, \mathrm{Ni}, \\
\gamma-\mathrm{Al}_{2} \mathrm{O}_{3}, \\
\mathrm{CaO} 2 \mathrm{Al}_{2} \mathrm{O}_{3}, \\
\mathrm{CaCO}_{3} \\
\end{array}$ & 165 & 170 \\
\hline $\begin{array}{l}\text { Meth 134 } \\
\text { (C13-04-4) }\end{array}$ & $5 / 3$ & 120 & 50 & $\begin{array}{l}\mathrm{NiO}, \mathrm{Ni}, \\
\gamma-\mathrm{Al}_{2} \mathrm{O}_{3} \\
\mathrm{CaCO}_{3}\end{array}$ & 180 & 180 \\
\hline $\begin{array}{l}\text { Meth 135 } \\
\text { (C13-03-3) }\end{array}$ & $5 / 2$ & 66 & 57 & $\begin{array}{l}\mathrm{Ni}, \mathrm{NiO} \\
\gamma-\mathrm{Al}_{2} \mathrm{O}_{3}, \\
\mathrm{CaCO}_{3}\end{array}$ & 175 & 180 \\
\hline
\end{tabular}




\section{Summary}

In the present study raw Ni-alumina catalyst NIAP-07-01 (NKM-1) and Nicement-containing catalysts NIAP-07-07 (NKM-7), Meth-134 (C13-04-4) and Meth-135 (C13-03-3), as well as the same catalysts activated and pre-treated with aqueous MDEA solution in the flow of nitrogen-hydrogen gas mixture (NHM), were investigated. After the exposure to MDEA investigated catalysts almost completely retain their values of mechanical strength, specific surface area, porosity and catalytic activity, the latter being around $165-180{ }^{\circ} \mathrm{C}$. The active component $(\mathrm{Ni})$ in the catalysts subjected to the MDEA solution exposure is highly dispersed after the subsequent activation, which contributes to the elevated cata- lytic activity. During the treatment of a catalyst by the MDEA aqueous solution in the flow of NHM at $320^{\circ} \mathrm{C}$ its passivation takes place. By using the temperatureprogrammed reduction it was proven that the surface of catalysts is blocked by MDEA. During the reduction of the catalysts treated with MDEA $\mathrm{CO}_{2}$ - one of the MDEA decomposition products - is released to the gas phase, which further reinforces our assumptions.

Regeneration of the activated methanation catalysts subjected to (and inhibited by) MDEA should be carried out by drying them in the $\mathrm{NHM}$ at temperatures higher than $150-200{ }^{\circ} \mathrm{C}$, followed by additional reduction at temperatures of $350-400{ }^{\circ} \mathrm{C}$.

\section{In Russian}

\section{Введение}

В течение длительного времени в СССР, РФ и СНГ основными катализаторами, применяющимися в процессе гидрирования оксидов углерода (метанирования), являются разработанные в «НИАП-КАТАЛИЗАТОР» никель-алюминиевый катализатор марки НИАП-07-01 (НКМ-1), никель-цементсодержащий НИАП-07-02, НИАП-07-03 (НКМ-4А) и никель-алюмохромовый ТО-2М [1-5]. Катализаторы изготавливаются по ТУ 2178-003-00209510-2006 катализаторным производством «НИАП-КАТАЛИЗАТОР», а до недавнего времени выпускались также Дорогобужской катализаторной фабрикой и Северо-Донецким катализаторным производством. В настоящее время в РФ катализаторы изготавливаются только катализаторным производством
«НИАП-КАТАЛИЗАТОР». Катализаторы, произведенные в «НИАП-КАТАЛИЗАТОР», при соблюдении регламентных режимов эксплуатации работают по 15-16 лет, а на трех ПО «АЗОТ» (Hевинномысск, Тольятти, Гродно) срок их службы составил 22-24 года [6].

Кроме того, применяются импортные катализаторы, основными поставщиками которых являются такие фирмы, как Haldor Topsoe, Johnson Matthey и CLARIANT (Sud-Chemie). Отечественные катализаторы изготавливаются в форме таблеток или колец (таблетирование) в соответствии с техническими требованиями ТУ 2178-003-00209510-2006 (катализаторы метанирования). Для российского рынка импортные катализаторы предлагаются в виде таблеток, а также в форме экструдатов и шариков. 
Катализаторы метанирования должны иметь высокую активность в процессе гидрирования 0,3-0,7\% $\mathrm{CO}$ и $0,02-0,1 \% \mathrm{CO}_{2}$ до остаточного содержания CO 5-10 ppm, термостабильность без снижения активности при перегревах до $550-650{ }^{\circ} \mathrm{C}$, которые могут возникать в случае повышения содержания оксидов углерода в исходном газе $\geq 1 \%$, высокую механическую прочность и пониженное гидравлическое сопротивление.

Качество катализаторов метанирования в значительной степени определяется носителем, используемым в процессе его приготовления. В отечественных и импортных промышленных катализаторах метанирования в качестве носителя, как правило, применяют $\gamma-\mathrm{Al}_{2} \mathrm{O}_{3}$, алюминаты кальция, композиции $\mathrm{CaO}-\mathrm{MgO}, \gamma-\mathrm{Al}_{2} \mathrm{O}_{3}-\mathrm{Cr}_{2} \mathrm{O}_{3}$, $\gamma$ - $\mathrm{Al}_{2} \mathrm{O}_{3}$-алюминат кальция, бемит $(\mathrm{AlOOH})-\gamma-\mathrm{Al}_{2} \mathrm{O}_{3}$ [7-9].

Содержание активного компонента (NiO) в промышленных катализаторах метанирования варьируется в пределах 25,0-45,0 масс.\%. Катализаторы НИАП-07-02, НИАП-07-03, a также KATALKO-11-4R, Meth-134 и Meth-135, в которых алюминат кальция выполняет роль гидравлического вяжущего, имеют минимальный уровень внутренних микронапряжений, что способствует сохранению на высоком уровне механической прочности после стадии активации и последующего периода эксплуатации.

Срок эксплуатации катализаторов определяется в первую очередь такими показателями, как каталитическая активность и механическая прочность.

Мировой опыт эксплуатации промышленных катализаторов, применяющихся в различных процессах химической, нефтехимической, металлургической и др. отраслях, а также имеющиеся в литературе данные и наши многолетние наблюдения за работой в промышленных условиях катализаторов, разработанных в «НИАП-КАТАЛИЗАТОР», позволили во многом оценить причины их дезактивации. Дезактивация катализаторов метанирования может происходить, например, вследствие:

1. Необратимого отравления, связанного с взаимодействием активного компонента с каталитическими ядами (сернистые соединения, хлориды и т.д.), присутствующих в реакционной среде.

2. Термического воздействия - рекристаллизация, спекание, взаимодействие активного компонента с носителем. Например, образование никель-алюминиевой шпинели $\left(\mathrm{NiAl}_{2} \mathrm{O}_{4}\right)$.

3. Унос активного компонента за счет образования летучих соединений (например, образование карбонила никеля).

4. Зауглероживание.

5. Загрязнение поверхности механическими примесями.

Структурные изменения промышленных катализаторов, которые представляют собой пористые высокодисперсные тела, ускоряются, если в них происходят фазовые превращения при воздействии реакционной среды.

В условиях работы агрегатов большой единичной мощности по производству синтетического аммиака источником катализаторных ядов могут служить абсорбенты, применяющиеся для удаления $\mathrm{CO}_{2}$ из синтезгаза или продукты их разложения. В промышленных условиях этот процесс происходит в абсорберах с помощью таких абсорбентов, как вод- 
ные щелочные растворы («Бенфийлд» и «Карсол»), а также органических поглотителей в виде водных растворов активированных моноэтаноламина (МЭА) или метилдиэтаноламина (МДЭА) $[10,11]$. В процессе эксплуатации наблюдаются уносы абсорбентов диоксида углерода в реактор метанирования. Результатом этого нарушения технологического процесса, как правило, является увеличение газодинамического сопротивления метанатора и постепенное падение каталитической активности $[12,13]$.

Для выяснения причин этого явления нами были проведены исследования, в которых катализаторы метанирования были подвергнуты максимально жесткому воздействию органического абсорбента МДЭА.

\section{Экспериментальная часть}

В качестве объектов исследований были взяты промышленный катализатор НИАП-07-01 (НКМ-1) и рекомендуемый для промышленного внедрения катализатор НИАП-07-07 (НКМ-7) в двух его состояниях: 1 - непрокаленный; 2 - прокаленный при 400 ㄷ. Из одной и той же непрокаленной катализаторной шихты он может изготавливаться в виде цилиндрических таблеток, экструдатов или в кольцевидной форме. Катализатор в форме колец обладает низким газодинамическим сопротивлением, что приводит к существенной экономии природного газа при эксплуатации агрегата синтеза аммиака. Кроме того, были исследованы импортные катализаторы марки Meth-135 (C13-03-3) и Meth-134 (C13-04-4).

Рентгенографические исследования с определением фазового состава и дисперсности кристаллитов проводили с использованием дифрактометра ДРОН-3 (CuKa-излучение с графитовым монохроматором на отраженном пучке). Для идентификации фаз использовали базу данных Международного комитета порошковых дифракционных стандартов (ICDD PDF-2, 1999 г.). Комплексные термические исследования осуществ- ляли с применением оптического дериватографа марки OD-103 (линейная скорость нагрева 5 $\mathrm{C} / \mathrm{мин})$. Общую удельную поверхность определяли по низкотемпературной адсорбции азота на вакуумной адсорбционной установке. Общую пористость рассчитывали по данным истинной и кажущейся плотности. Механическая прочность определялась на приборе «МП-2С» раздавливанием гранул с приложением нагрузки на торец. Химический состав и каталитическую активность в процессе метанирования на пилотной установке при давлении $3 \mathrm{MПа}$ определяли по методикам, приведенным в ТУ 2178-003-00209510.

Химический состав и каталитическую активность в процессе метанирования на пилотной установке при давлении 3 МПа определяли по методикам, приведенным в ТУ 2178-003-00209510. За меру каталитической активности принята минимальная температура $\left({ }^{\circ} \mathrm{C}\right)$, обеспечивающая объемную долю СО на выходе не более $1 \cdot 10^{-3}$ об.\% при давлении 3 МПа, объемной скорости 4000 ч $^{-1}$, объемной доле в исходном газе 0,6-0,7 об.\% СО после предварительного перегрева катализатора при температуре $550{ }^{\circ} \mathrm{C}$ в течение 10 ч. 
Обработку всех исследуемых катализаторов $50 \%$-м водным раствором абсорбента МДЭА в потоке азото-водородной смеси (75 об.\% $\mathrm{H}_{2}, 25$ об.\% $\mathrm{N}_{2}$ ) проводили на установке, принципиальная схема которой приведена на рис. 1.

Перед проведением экспериментов осуществляли активацию катализато- ров в потоке азото-водородной смеси (АВС) при температуре $400{ }^{\circ} \mathrm{C}$ в течение 5 ч. По окончании процесса активации образцы подвергали при температуре $320^{\circ} \mathrm{C}$ воздействию водного раствора МДЭА в потоке АВС в слое катализатора.

\section{Результаты и обсуждение}

Для определения степени воздействия абсорбентов на катализаторы были определены их основные исходные характеристики (табл. 1).

Из данных, приведенных в табл. 1, видно, что исследуемые катализаторы имеют концентрацию активного компонента в пересчете на $\mathrm{NiO}$ в пределах 27-40 масс.\%. Дисперсность $\mathrm{NiO}$ в катализаторах НИАП-07-01 (НКМ-1) и НИАП-07-07 (НКМ-7) находится на уровне 60-80 А․ Показатель общей пористости практически одинаков для

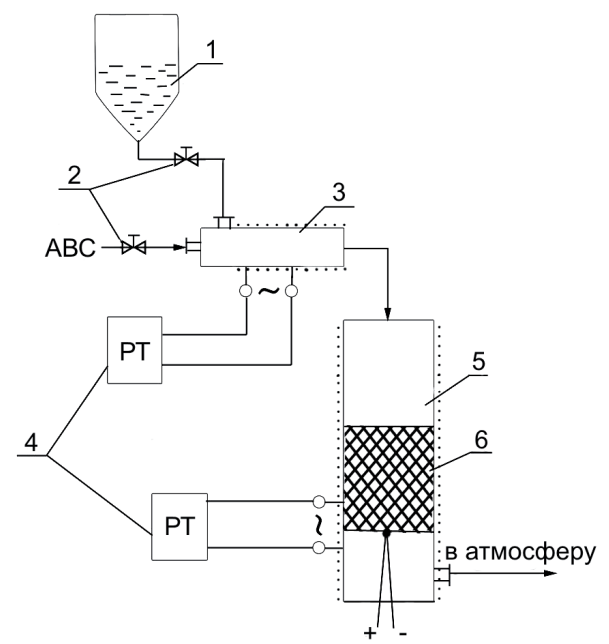

Рис. 1. Принципиальная схема установки для обработки катализатора в потоке азота или азото-водородной смеси с водными растворами абсорбентов: 1 - раствор МДЭА; 2 - регуляторы расхода; 3 - испаритель; 4 - регулятор температуры; 5 - реактор; 6 - катализатор всех катализаторов и находится на уровне 48-57\%. Исключение составляет катализатор НИАП-07-07, для которого значение общей пористости составляет $29 \%$. Это явление объясняется тем, что формирование пористой структуры этого катализатора происходит в совмещенном процессе прокаливания и активации. Сопоставление данных по общей удельной поверхности показывает, что все катализаторы имеют высокоразвитую общую удельную поверхность. Максимальное ее

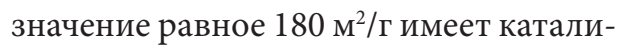
затор НИАП-07-01 (НКМ-1).

Можно отметить значительный разброс для катализаторов по такому показателю, как механическая прочность, которая во многом определяет срок службы катализаторов. По этому показателю наибольшее предпочтение можно отдать катализатору НИАП-07-07 (НКМ-7), для которого ее значение равно $60 \mathrm{MПа.} \mathrm{На}$ второе место можно поставить катализатор НИАП-07-01 (НКМ-1) - 29 МПа. Катализаторы Meth-134 и Meth-135 по своим прочностным показателям практически одинаковы.

Анализ фазового состава и дисперсности $\mathrm{NiO}$ (табл. 1) свидетельствует о том, что в качестве одного из компонентов носителя катализаторов Meth-134, Meth-135 и НИАП-07-07 
(НКМ-7) применяется алюминатный цемент. Если в катализаторах серии НИАП-07 (НКМ) вторым компонентом носителя является $\gamma-\mathrm{Al}_{2} \mathrm{O}_{3}$, то в катализаторах Meth-134 и Meth-135 применяется смесь гидрооксида алюминия в виде его модификации «бемит» $(\mathrm{AlOOH})$ и $\gamma-\mathrm{Al}_{2} \mathrm{O}_{3}$. Применение в катализаторах Meth-134 и Meth-135 гидрооксида алюминия в виде его модификации «бемит» приводит к недостаточно глубокому его взаимодействию с прекурсором активного компонента, что неизбежно будет сказываться на каталитической активности.

Отличие исходного образца катализатора НИАП-07-07 от НИАП-07-01 (НКМ-1), прокаленного НИАП-07-07 (НКМ-7) и катализатора марки Meth состоит в том, что его активный компонент находится в виде сложного химического соединения (гидроксокарбо-

алюминат никеля - ГКАН). Активация этого катализатора, совмещенная с разложением ГКАН, происходит при более низких температурах и в более мягких условиях по сравнению с другими промышленными катализаторами, в которых активный компонент находится в оксидной форме.

Так как эксплуатация катализаторов в промышленных условиях агрегатов синтеза аммиака осуществляется при температурах $280-320^{\circ} \mathrm{C}$, в этом же температурном интервале была определена термическая устойчивость МДЭА, данные по которой в справочной литературе отсутствуют. С этой целью образец $\alpha-\mathrm{Al}_{2} \mathrm{O}_{3}$ был пропитан до состояния насыщения водным раствором МДЭА, который затем был исследован дериватографическим методом анализа. На рис. 2 приведена дериватограмма данного образца.

Таблица 1 Физико-механические и физико-химические характеристики исходных катализаторов метанирования: П - пористость, Sуд - удельная поверхность,

$\mathrm{LNiO}$ - дисперсность частиц $\mathrm{NiO}$

\begin{tabular}{|c|c|c|c|c|c|c|c|c|c|c|}
\hline \multirow{2}{*}{$\begin{array}{c}\text { Марка ката- } \\
\text { лизатора }\end{array}$} & \multirow{2}{*}{$\begin{array}{l}\text { Геометри- } \\
\text { ческие } \\
\text { размеры, } \\
\text { мм }\end{array}$} & \multirow{2}{*}{$\begin{array}{c}\text { На- } \\
\text { сыпная } \\
\text { плот- } \\
\text { ность, } \\
\text { кг/дм }\end{array}$} & \multirow{2}{*}{$\begin{array}{c}\text { Механи- } \\
\text { ческая } \\
\text { прочность, } \\
\text { МПа на } \\
\text { торец } \\
\mathrm{P}_{\text {ср. }} / \mathrm{P}_{\text {min }}\end{array}$} & \multirow{2}{*}{$\begin{array}{l}\text { Суд., } \\
\mathrm{M}^{2} / \Gamma\end{array}$} & \multirow{2}{*}{$\begin{array}{c}\Pi, \\
\%\end{array}$} & \multirow[b]{2}{*}{ РФА } & \multirow{2}{*}{$\begin{array}{c}\mathrm{L}_{\mathrm{NiO}} \\
\AA\end{array}$} & \multicolumn{3}{|c|}{$\begin{array}{l}\text { Хим. состав, } \\
\% \text { масс. }\end{array}$} \\
\hline & & & & & & & & & $\mathrm{Al}_{2} \mathrm{O}_{3}$ & $\mathrm{CaO}$ \\
\hline $\begin{array}{c}\text { НИАП-07-01 } \\
\text { (НКМ-1) }\end{array}$ & $\begin{array}{c}\text { Таблетка } \\
6 \times 5\end{array}$ & 1,08 & $29 / 20$ & 180 & 57 & $\begin{array}{c}\gamma-\mathrm{Al}_{2} \mathrm{O}_{3}, \mathrm{NiO}, \\
\text { графит }\end{array}$ & 60 & 33,6 & 61,3 & - \\
\hline $\begin{array}{c}\text { НИАП-07-07 } \\
\text { (НКМ-7) }\end{array}$ & $\begin{array}{c}\text { Таблетка } \\
6 \times 5\end{array}$ & 1,2 & $60 / 52$ & 102 & 29 & \begin{tabular}{|c|} 
ГКАН, графит, \\
$\mathrm{CaCO}_{3}$ (арагонит) - \\
мало, $\mathrm{Al}(\mathrm{OH})_{3}$, \\
$\mathrm{CaO} \cdot 2 \mathrm{Al}_{2} \mathrm{O}_{3}-$ мало \\
\end{tabular} & - & 30,3 & 25,2 & 7.9 \\
\hline $\begin{array}{c}\text { НИАП-07-07 } \\
\text { (НКМ-7) } \\
\text { прокален при } \\
450^{\circ} \mathrm{C}\end{array}$ & $\begin{array}{c}\text { Таблетка } \\
6 \times 5\end{array}$ & 1,1 & $49 / 32$ & 160 & 53 & $\begin{array}{c}\mathrm{NiO}, \gamma-\mathrm{Al}_{2} \mathrm{O}_{3}, \\
\mathrm{CaO} \cdot \mathrm{Al}_{2} \mathrm{O}_{3}, \\
\mathrm{CaO} \cdot 2 \mathrm{Al}_{2} \mathrm{O}_{3}, \text { графит }\end{array}$ & 75 & 30,3 & - & - \\
\hline $\begin{array}{l}\text { Meth-134 } \\
\text { (C13-04-4) }\end{array}$ & $\begin{array}{l}\text { Шарик } \\
d=4,3\end{array}$ & 0,95 & $8 / 4$ & 150 & 48 & $\begin{array}{c}\mathrm{NiO}, \mathrm{AlOOH}, \\
\gamma-\mathrm{Al}_{2} \mathrm{O}_{3}, \mathrm{CaCO}_{3} \\
\text { (бемит) }\end{array}$ & 80 & 27,2 & 57,3 & 10,0 \\
\hline $\begin{array}{l}\text { Meth-135 } \\
\text { (C13-03-3) }\end{array}$ & $\begin{array}{l}\text { Шарик } \\
d=5,3\end{array}$ & 0,99 & $6 / 1$ & 120 & 54 & $\begin{array}{c}\mathrm{NiO}, \mathrm{AlOOH}, \\
\gamma-\mathrm{Al}_{2} \mathrm{O}_{3}, \mathrm{CaCO}_{3} \\
\text { (бемит) }\end{array}$ & 80 & 40,4 & 42,9 & 11,2 \\
\hline
\end{tabular}




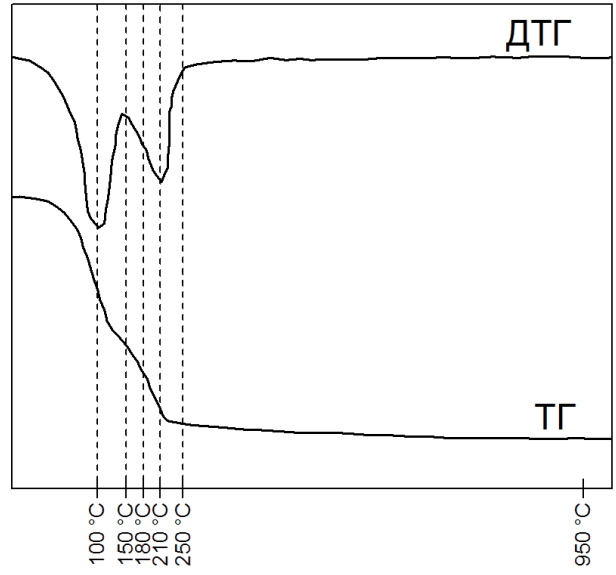

Рис. 2. Дериватограмма образца $\alpha-\mathrm{Al}_{2} \mathrm{O}_{3}$, пропитанного до состояния насыщения раствором МДЭА

На дериватограмме имеются два ярко выраженных эффекта с характеристическими температурами $T_{\text {max }}=100{ }^{\circ} \mathrm{C}$ и $T_{\text {max }}=210^{\circ} \mathrm{C}$, которые соответствуют удалению из образца физически связанной влаги и разложению МДЭА. Процесс разложения МДЭА в среде воздуха сопровождается убылью массы. Начинается он при температуре $150{ }^{\circ} \mathrm{C}$, а его максимальная скорость достигается при $210{ }^{\circ} \mathrm{C}$. Заканчивается разложение МДЭА при $300{ }^{\circ} \mathrm{C}$.
Для определения оптимальной температуры активации катализаторов были проведены исследования температурно-программированного восстановления. Было установлено, что этот процесс является многостадийным. Кроме того, было обнаружено, что катализатор НИАП-07-07 (НКМ-7) активируется $\sim$ на $100{ }^{\circ} \mathrm{C}$ ниже всех исследованных образцов. Рентгенографические данные показали, что при температуре $400{ }^{\circ} \mathrm{C}$ происходит практически полная активация. Сопоставление данных по дисперсности $\mathrm{Ni}$ свидетельствует о том, что она для всех исследуемых катализаторов практически одинакова и находится в пределах $60 \div 80 \AA$.

В табл. 2 приведены физико-механические и физико-химические характеристики активированных исследуемых катализаторов метанирования с последующим воздействием на них водного раствора МДЭА в потоке АВС, а также их каталитическая активность в процессе метанирования. Характерной особенностью экспериментов по воздействию водного раствора МДЭА на активированные катализаторы метанирования было то, что в начальный

Таблица 2

Физико-механические и физико-химические характеристики катализаторов

\begin{tabular}{|c|c|c|c|c|c|c|}
\hline \multirow[b]{3}{*}{$\begin{array}{c}\text { Марка } \\
\text { катализатора }\end{array}$} & & 1нировағ & я по & обработки МДЭ & & \\
\hline & \multirow[b]{2}{*}{$\begin{array}{l}\text { Механическая } \\
\text { прочность, МПа } \\
\text { на торец } \mathrm{P}_{\text {ср. }} / \mathrm{P}_{\min }\end{array}$} & \multirow[b]{2}{*}{ Sуд., $\mathbf{M}^{2} / \Gamma$} & \multirow[b]{2}{*}{ П, \% } & \multirow[b]{2}{*}{ РФА } & \multicolumn{2}{|c|}{ Активность, $\mathrm{T}_{\text {пр. }}{ }^{\circ} \mathrm{C}$} \\
\hline & & & & & $\begin{array}{l}\text { Исходных } \\
\text { образцов }\end{array}$ & $\begin{array}{c}\text { После } \\
\text { воздействия } \\
\text { МДЭА }\end{array}$ \\
\hline $\begin{array}{l}\text { НИАП-07-01 } \\
\text { НКМ-1 }\end{array}$ & $27 / 19$ & 155 & 54 & $\begin{array}{c}\mathrm{NiO}, \mathrm{Ni} \text {, графит, } \\
\gamma-\mathrm{Al}_{2} \mathrm{O}_{3}\end{array}$ & 160 & 165 \\
\hline $\begin{array}{c}\text { НИАП-07-07 } \\
\text { НКМ-7 }\end{array}$ & $41 / 35$ & 168 & 41 & $\begin{array}{c}\mathrm{NiO}, \mathrm{Ni}, \gamma-\mathrm{Al}_{2} \mathrm{O}_{3}, \\
\mathrm{CaO} \cdot 2 \mathrm{Al}_{2} \mathrm{O}_{3}, \mathrm{CaCO}_{3}\end{array}$ & 165 & 170 \\
\hline $\begin{array}{l}\text { Meth-134 } \\
(\mathrm{C} 13-04-4) \\
\end{array}$ & $5 / 3$ & 120 & 50 & $\begin{array}{c}\mathrm{NiO}, \mathrm{Ni}, \gamma-\mathrm{Al}_{2} \mathrm{O}_{3}, \\
\mathrm{CaCO}_{3}\end{array}$ & 180 & 180 \\
\hline $\begin{array}{l}\text { Meth-135 } \\
\text { (C13-03-3) }\end{array}$ & $5 / 2$ & 66 & 57 & $\begin{array}{c}\mathrm{Ni}, \mathrm{NiO}, \gamma-\mathrm{Al}_{2} \mathrm{O}_{3}, \\
\mathrm{CaCO}_{3}\end{array}$ & 175 & 180 \\
\hline
\end{tabular}


период подачи МДЭА в потоке АВС наблюдался рост температуры в слое катализатора, что связано с пассивирующим действием водяного пара, образующегося при испарении водного раствора МДЭА. Анализ дифрактограмм подтвердил что, в данном случае происходит пассивация активного компонента $\mathrm{Ni}$ и определенная его часть выводится из каталитического процесса. Свидетельством этого является наличие в фазовом составе активированных катализаторов, подвергнутых воздействию водного раствора МДЭА в потоке АBC, фаз $\mathrm{Ni}$ и $\mathrm{NiO}$. Соотношение этих фаз, по всей видимости, зависит от степени восстановленности и от содержания металлического никеля в каждом конкретном катализаторе. Исходя из этого, образцы перед проведением испытаний активности были предварительно восстановлены при $400{ }^{\circ} \mathrm{C}$ в течение 8 ч.

По данным РФА, МДЭА не оказывает химического воздействия на носители исследуемых катализаторов метанирования. Однако в связи с тем, что МДЭА (третичный амин) является адсорбционно-активным веществом, он может негативно сказаться на свойствах катализаторов, и в первую очередь на таких его характеристиках, как механическая прочность, общая удельная поверхность, пори- стость и каталитическая активность. Результаты исследований, приведенные в табл. 2, показывают, что после воздействия на активированные катализаторы водного раствора МДЭА с одновременным потоком АВС произошло незначительное снижение механической прочности и общей удельной поверхности. Исключение составляет катализатор НИАП-07-07 (НКМ-7), у которого формирование текстуры происходит в процессе активации. Общая пористость для всех образцов практически одинакова. Произошли изменения в фазовом составе, связанные с процессом пассивации катализаторов. Сравнение данных по каталитической активности, полученных в данном эксперименте, показывает, что катализаторы, подвергнутые при $320{ }^{\circ} \mathrm{C}$ воздействию водного раствора МДЭА в потоке АВС после предварительной активации, практически не теряют своих каталитических свойств. Данный показатель хорошо сопоставим со значениями активности (по ТУ 2178-003-00209510-2006) катализаторов метанирования, имеющих содержание активного компонента (NiO) от 31 до $40 \%$. Для катализаторов с таким содержанием активного компонента каталитическая активность находится в пределах от 170 до $200{ }^{\circ} \mathrm{C}$.

\section{Выводы}

Комплексом физико-механических и физико-химических методов исследованы характеристики $\mathrm{Ni-Al}$ катализатора НИАП-07-01 (НКМ-1) и Ni-цементсодержащих катализаторов марки НИАП-07-07 (НКМ-7), Meth-134 (С1304-4) и Meth-135 (C13-03-3) как исходных катализаторов, так и активиро- ванных с последующим воздействием на них водного раствора МДЭА в потоке АВС. Исследуемые катализаторы после воздействия на них водного раствора МДЭА в потоке АВС практически сохраняют высокие значения механической прочности, общей удельной поверхности, пористости 
и каталитической активности, которая находится на уровне $165-180{ }^{\circ} \mathrm{C}$. Установлено, что активный компонент (Ni) в катализаторах, обработанных МДЭА с последующей активацией, находится в дисперсном состоянии, что предопределяет их высокую каталитическую активность. В процессе воздействия на активированные катализаторы при температуре $320{ }^{\circ} \mathrm{C}$ водного раствора МДЭА в потоке АВС происходит их пассивация. Методом температурнопрограммированного восстановления установлено, что поверхность катализаторов блокируется МДЭА. Это предположение подтверждается выделением в процессе восстановления обработанных катализаторов в газовую фазу $\mathrm{CO}_{2}$, являющегося одним из продуктов разложения МДЭА.

Регенерация в промышленных условиях активированных катализаторов метанирования, подвергшихся воздействию водного раствора МДЭА, должна осуществляться путем их сушки в потоке $\mathrm{ABC}$ при температурах не ниже $150-200{ }^{\circ} \mathrm{C}$ с последующим довосстановлением при температурах $350-400{ }^{\circ} \mathrm{C}$.

\section{References}

1. Golosman EZ, Efremov VN, Kreyndel' AI, Mironov YuV, Obysov AV, Sobolevskiy VS, Yakerson VI, inventors; Men'shov VN, assignee. Russian Federation patent RU2143320. 27.12.1999. Russian.

2. Golosman EZ, Efremov VN. Promyshlennye katalizatory gidrirovaniya oksidov ugleroda [Industrial catalysts for the carbon oxides hydrogenation]. Kataliz $v$ promyshlennosti. 2012;(5):36-55. Russian. DOI:10.18412/1816-0387-2012-5-36-55.

3. Alekseev AM. Iz istorii kataliza [History of catalysis]. Moscow: Kal'vis, 2005. [Chapter], GIAP v istorii katalizatornoy promyshlennosti SSSR i Rossii [GIAP in the history of catalysis industry of USSR and Russia]; p. 481-532. Russian.

4. Melnikov EYa, editor. Spravochnik azotchika. 2nd ed. Moscow: Chemistry, 1987. 512 p. Russian.

5. Demidenko IM, Yankovskiy NA, Stepanov VA, Nikitina EF, Kravchenko BV. Katalizatory i protsessy s ikh primeneniem v azotnoy promyshlennosti [Catalysts and processes with their application in the nitric industry]. Gorlovka: Gorlovskaya tipografiya, 1998. 198 p. Russian.

6. Efremov VN, Kashinskaya AV, Polivanov BI, Boevskaya EA, Golosman EZ. O razrushenii katalizatora metanirovaniya pod vozdeystviem vodnogo rastvora potasha [Destruction of the methanation catalyst by water solution of $\mathrm{KOH}$. Part I: The nickel-alumina catalyst NIAP-07-01 (NKM-1)]. Neftegazokhimiya. 2015;4:62-6. Russian.

7. Takenara S, Shimizu T, Otsuka K. Complete removal of carbon monoxide in hydrogen-rich gas stream through methanation over supported metal catalysts. Int J Hydrogen Energy. 2004;29(10):1065-73. DOI:10.1016/j.ijhydene.2003.10.009.

8. Men Y, Kolb G, Zapf R, Hessel V, Love H. Selective methanation of carbon oxides in a microchannel reactor-Primary screening and impact of gas additives. Catal Today. 2007;125(1-2):81-7. DOI:10.1016/j.cattod.2007.02.017. 
9. Liu Q, Dong X, Mo X, Lin W. Selective catalyc methanation of CO in hydrogen-rich gases over $\mathrm{Ni} / \mathrm{ZrO}_{2}$ catalyst. J Natur Gas Chem. 2008;17(3):268-72. DOI:10.1016/ S1003-9953(08)60062-6.

10. Leites IL, Avetisov AK, Yazvikova NV, Suvorkin SV, Baichtok CK, Dudakova NV, Deev KN, Kosarev GV. Issledovanie fiziko-khimicheskikh svoystv modifitsirovannogo MEDA-absorbenta dlya tonkoy ochistki gaza ot dioksida ugleroda v proizvodstve ammiaka [Investigation of physico-chemical properies of modified MDEAabsorbent for fine purification of gas from carbon dioxide in ammonia production]. Khimicheskaya promyshlennost' segodnya. 2003;1:34-41. Russian.

11. Avetisov AK, Kononov SM, Sokolov AM, Baichtok CK, Suvorkin SV, Leites IL, Deripasov VV, Sokolinskiy CA, Yazvikova NV. Opyt modernizatsii otdeleniya absorbtsionnoy ochistki agregata sinteza ammiaka AM-70 na OAO «Nevinnomysskiy Azot» s zamenoy MEA-rastvora na MDEA-absorbent rossiyskogo proizvodstva [Experience of modernization of absorption purification unit of the ammonia-synthesis plant AM-70 at JSC «Nevinnomysskiy Azot»: replacement of the MEA solution by MDEA-absorbent made in Russia]. Khimicheskaya promyshlennost' segodnya. 2003;2:22-4. Russian.

12. Vakk EG, Shuklin GV, Leites IL. Poluchenie tekhnologicheskogo gaza dlya proizvodstva ammiaka, metanola, vodoroda i vysshikh uglevodorodov. Teoreticheskie osnovy, tekhnologiya, katalizatory, oborudovanie, sistemy upravleniya [Obtaining of gas for production of ammonia, methanol, hydrogen and higher hydrocarbons. Theoretical foundations, technology, catalysts, equipment, management: a textbook]. Moscow, 2001. 478 p. ISBN978-5-98801-033-3. Russian.

13. Efremov VN, Golosman EZ, Polivanov BI, Kashinskaya AV, Polushin AP. Ustoychivost' nikelevykh promyshlennykh katalizatorov metanirovaniya k vozdeystviyu aktivirovannogo metildietanolamina - absorbent $\mathrm{CO}_{2}$ [Stability of Industrial Nickel Catalysts for Methanation against the Action of Activated Methyldiethanol Amine used as $\mathrm{CO}_{2}$ Absorbent]. Kataliz v promyshlennosti. 2016;16(4):67-76. Russian. DOI:10.18412/1816-0387-2016-4-67-76.

\section{Cite this article as:}

Efremov VN, Golosman EZ, Kashinskaya AV, Mugenov TI, Zolotareva VE, Polivanov BI, Polushin AP. Resistance of industrial nickel-containing methanation catalysts to the poisoning by organic carbon dioxide absorbents. Chimica Techno Acta. 2017;4(3):16782. DOI:10.15826/chimtech/2017.4.3.02. 